Original paper

\title{
Origin of mantle peridotites from the Vourinos Ophiolite Complex, Greece, as deduced from Cr-spinel morphological and chemical variations
}

\author{
Argyrios N. KAPSIOTIS
}

Department of Geology, Section of Earth Materials, Panepistimiopolis of Rion, University of Patras, 26504 Patras, Greece; Present address: Leoforos Salaminas 194, Salamina, 18900, Greece; kapsiotisa@yahoo.gr

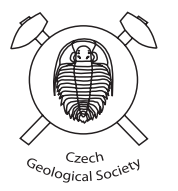

The Vourinos Ophiolite Complex in north-western Greece represents a fragment of oceanic lithosphere emplaced after the Late Jurassic closure of the Neotethyan Pindos Ocean. This Ophiolite Complex consists mainly of a well-preserved mantle sequence dominated by peridotite and chromitite. Based on petrographic features, four distinct peridotite varieties can be distinguished in the Vourinos mantle suite: i) normal harzburgite (Opx $\geq 15$ vol. \%), ii) transitional harzburgite $(\mathrm{Opx}<15$ vol. \%), iii) coarse-grained dunite and iv) fine-grained dunite. Chromian spinel morphology, based on DR\# (degree of roundness) measurements, varies systematically from harzburgitic to dunitic rocks. Anhedral chromian spinel occurs in normal harzburgite $(\mathrm{DR} \#<0.40)$, whereas in the other studied peridotite types this mineral is more euhedral (DR\# > 0.40). The $\mathrm{Cr} \#[\mathrm{Cr} /(\mathrm{Cr}+\mathrm{Al})]$ in chromian spinel increases from normal harzburgite to coarse-grained dunite, varying between 0.47 and 0.84 . Such a variation in chromian spinel composition indicates a multi-stage melting evolution for the Vourinos mantle suite. Chromian spinel from the fine-grained dunite bears similarities in terms of $\mathrm{Cr} \#$ and $\mathrm{Mg} \#\left[\mathrm{Mg} /\left(\mathrm{Mg}+\mathrm{Fe}^{2+}\right)\right]$ with chromian spinel from the neighboring chromitites, which implies a common origin for both lithologies. Chromian spinel morphological and compositional data indicate that after chromitite and fine-grained dunite formation a remnant boninite melt could have invaded the adjacent peridotites, modifying their accessory chromian spinels or even crystallizing new chromian spinel grains. Further evidence for that episode of melt percolation is provided by a few harzburgitic rock samples, which may be locally enriched in LREE exhibiting U-shaped chondrite-normalized REE patterns. Such patterns are characteristic of interaction between the depleted mantle peridotite and hydrous boninitic melt. The studied peridotites are interpreted as refractory residues whose initial composition was locally modified by mantle metasomatism in the fore-arc region of a supra-subduction zone.

Keywords: chromian spinel, partial melting, mantle metasomatism, peridotites, ophiolites Received: 27 November 2012; accepted: 13 August 2013; handling editor: M. Štemprok

\section{Introduction}

Chromian spinel is generally regarded as one of the most sensitive indicators used to constrain the petrogenesis of mantle peridotites (e.g., Dick and Bullen 1984; Arai 1992; Hellebrand et al. 2001; Kamenetsky et al. 2001; Mikuš and Spišiak 2007; Uysal et al. 2007; Ismail et al. 2009; González-Jiménez et al. 2011). Variations in morphology of accessory chromian spinel from peridotites have been described long ago (e.g., Mercier and Nicolas 1975; Arai 1980; Leblanc et al. 1980). In most cases the morphology of chromian spinel from ultramafic rocks is strongly dependent on lithology or may indicate different conditions of formation (e.g., temperature and/or order of crystallization). In addition, variations of chromian spinel composition in peridotites are also known to reflect differences in the processes involved in the evolution of upper mantle rocks, such as partial melting and mantle metasomatism (e.g., Kamenetsky et al. 2001; Kubo 2002; Arif and Jan 2006), or even in the geotectonic setting (Dick and Bullen 1984; Ishii et al. 1992). Combined stud- ies of morphological and chemical variations of chromian spinel in peridotites have shown that both properties are closely related to each other and are highly dependent on the genetic processes that have affected their host rocks (Matsumoto and Arai 2001). Moreover, deformation of mantle can affect either spinel morphology or composition. In particular spinel lineation is commonly interpreted as due to a relict asthenospheric flow (Nicolas and Poirier 1976), whereas stress-induced compositional zoning has been documented in spinels from deformed peridotites (Ozawa 1989).

Spinel peridotites are traditionally interpreted as solid residues after variable degrees of adiabatic melting of pristine mantle. However, there is now convincing evidence that migrating melts in the upper mantle may cause peridotite metasomatism (e.g., Kelemen et al. 1997; Zhou et al. 2005) or even refertilization (e.g., Dijkstra et al. 2001; Le Roux et al. 2007; Seyler et al. 2007). Interaction between melt and mantle peridotite is currently regarded as the most important petrologic process that takes place in the shallow mantle (e.g., Parkinson and Pearce 1998; 
Uysal et al. 2007; Dai et al. 2011), commonly leading to the formation of dunite and chromitite (e.g., Zhou et al. 2005).

The purpose of the present paper is to describe the morphological and chemical variations of accessory chromian spinel in conjunction with peridotite lithology from the Vourinos Ophiolite Complex, north-western Greece. The strongly depleted nature of the Vourinos peridotites has been interpreted to reflect a multi-stage mantle melting history. However, the present data indicate that - except for partial melting - another petrologic process was locally involved in the formation of the surrounding mantle rocks.

\section{Geological setting}

Ophiolites of northwestern continental Greece are considered as remnants after the progressive closure of the Neotethyan Ocean. Among these the Vourinos Ophiolite Complex has been extensively studied with regard to its structure, deformation and tectonic position (e.g., Moores 1969; Roberts et al. 1988; Ross and Zimmerman 1996; Rassios and Smith 2000; Rassios and Moores 2006; Ghikas 2007; Rassios and Dilek 2009).

The Vourinos Ophiolite Complex constitutes an almost complete ophiolitic suite of early to middle Jurassic age (Rassios and Smith 2000). It covers a total area of $450 \mathrm{~km}^{2}$; whereby $85 \%$ of the whole complex is composed of mantle peridotites (Fig. 1). The mantle suite consists mainly of massive harzburgite including deformed pods and layers of dunite. These dunite bodies range from several $\mathrm{m}$ up to a few $\mathrm{km}$ in size and commonly host chromitites. The mantle peridotites are frequently cross-cut by pyroxenite dykes. The contact between mantle rocks and ultramafic/mafic cumulates is sharp and intrusive (Harkins et al. 1980). Lowermost cumulates include dunite, which grades to wehrlite, pyroxenite and gabbronorite or troctolite. A sheeted dike complex is oriented perpendicularly to the magmatic layering of the cumulate rocks. Basaltic to andesitic massive lavas are found on the top of the sheeted dike complex, cut in turn by subordinate boninitic dykes in the Asprokambos area. Two different magmatic series can be distinguished in the Vourinos Ophiolite Complex: the regionally prevalent Krapa Series, having an islandarc tholeiite (IAT) affinity, and the Asprokambos Series which is younger and of boninitic chemistry (Beccaluva et al. 1984). Finally, the Ophiolite Complex is overlain by radiolarian cherts of Kimmeridgian age and, unconformably, by a thick section of Cenomanian limestones (Brunn 1956).

A sheared sedimentary wedge that exists between the basal harzburgites and the carbonate rocks of the

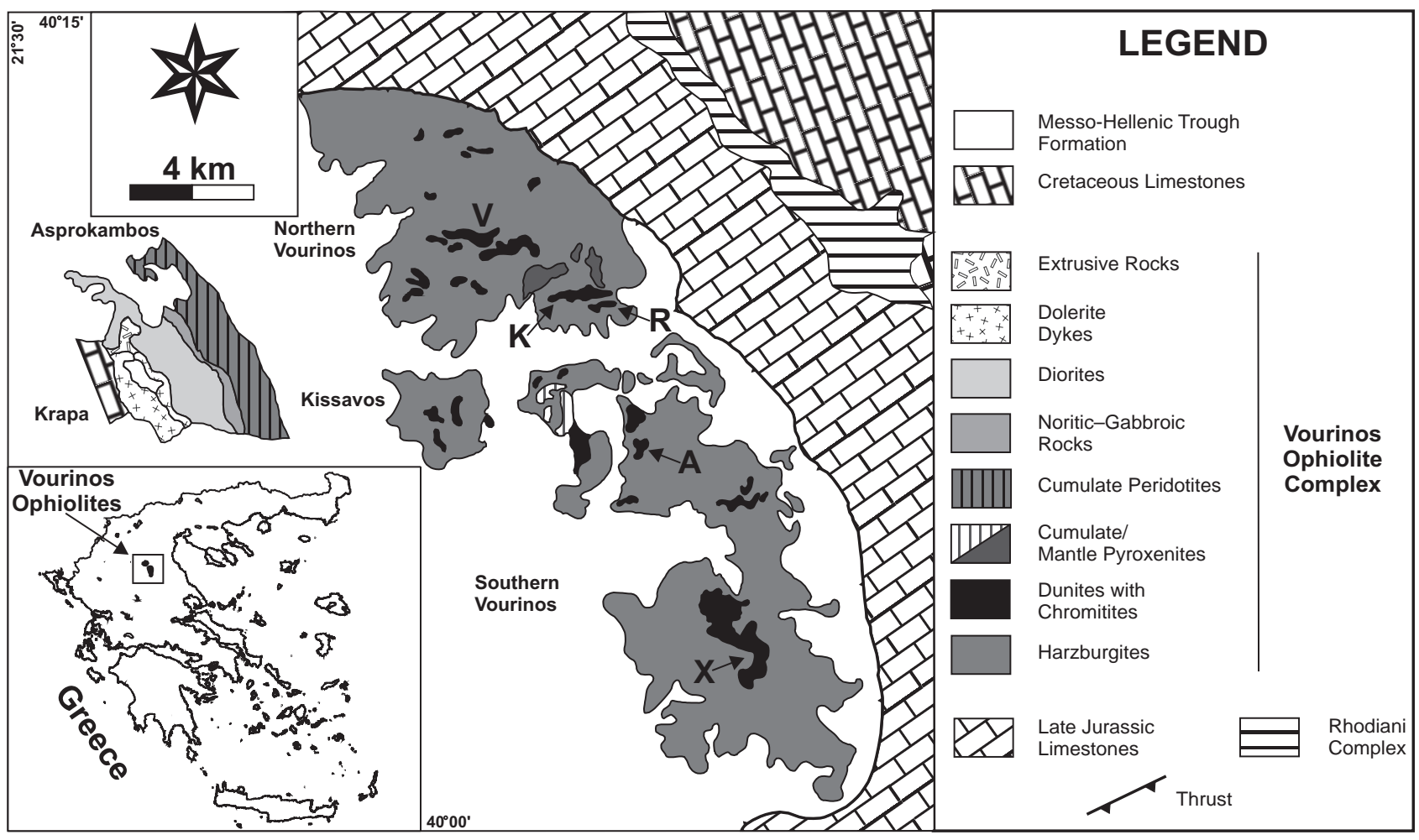

Fig. 1 Simplified geological map of the Vourinos Ophiolite Complex, showing the location of the studied areas (V: Voidolakkos district, K: Korsoumia district, R: Rizo district, A: Aetorraches district, X: Xerolivado district) [modified after Moores (1969); Rassios and Moores (2006); Ghikas (2007)]. 
Pelagonian Platform is thought to represent the Vourinos mélange (Ghikas et al. 2009). The metamorphic sole crops out at the eastern side of the Massif and is defined by restricted occurrences of amphibolite-facies metabasites with rare metasediments (e.g., Myhill 2011), some of which are garnet bearing (Rassios and Moores 2006). Spray and Roddick (1980) provided amphibole ${ }^{40} \mathrm{Ar} /{ }^{39} \mathrm{Ar}$ dates of the sole rocks (amphibolites) of Vourinos as 171 $\pm 4 \mathrm{Ma}$, whereas $\mathrm{U}-\mathrm{Pb}$ ion microprobe dating of comagmatic zircons from one gabbro and one plagiogranite yielded weighted mean ${ }^{206} \mathrm{~Pb} /{ }^{238} \mathrm{U}$ ages at $168.5 \pm 2.4$ and $172.9 \pm 3.1 \mathrm{Ma}$, respectively, interpreted as the time of formation of the Vourinos oceanic crust (Liati et al. 2004).

\section{Sampling and laboratory methods}

nimeter and a curvimeter, respectively. In order to obtain more accurate results on area and perimeter, new measurements were made on bitmap images using the image analysis program Leica Qwin. All the analyzed chromian spinel images were converted to black and white. Area and circumference were automatically estimated from the number of pixels forming the area or the perimeter converted to $\mathrm{mm}^{2}$ or $\mathrm{mm}$, respectively, using the scale definition. Representative results are listed in Tab. 1.

The quantitative chemical analyses of chromian spinel were performed using a Super JEOL JSM-6300 Scanning Electron Microscope (SEM) at the University of Patras. It was operated in Wavelength-Dispersive Spectrometry (WDS) mode at an acceleration voltage of $15 \mathrm{kV}$ and a beam current of $20 \mathrm{nA}$, with a beam diameter of c. $4 \mu \mathrm{m}$. The total counting time was $60 \mathrm{~s}$
Twenty seven representative peridotite samples were collected, which included all the main mantle rock types (except for pyroxenites) occurring in the Vourinos Ophiolite Massif. Care was taken to sample least serpentinized and most representative rocks from each mantle lithology. The peridotite samples come from its northern (Voidolakkos, Korsoumia and Rizo districts) and southern parts (Aetorraches and Xerolivado districts) (Fig. 1). A total of 4 up to 6 different peridotite samples were collected from each subarea of investigation, whereas at least two samples were taken from each main peridotite type (harzburgite and dunite) to unravel any possible petrographic heterogeneity. Each group of samples was collected within a few hundred $m$ from the chromitite exposures. In all cases the sampling began in dunite adjacent to chromitite and continued outwards.

The area and circumference of some chromian spinel grains were initially measured on photomicrographs taken under an optical microscope (Leica 550IW), using a pla-
Tab. 1 Representative morphological and compositional variations of chromian spinels from the studied peridotites

\begin{tabular}{|c|c|c|c|c|c|}
\hline Peridotite & Sample & DR\# & $\mathrm{Cr} \#$ & $\mathrm{TiO}_{2}$ & $\mathrm{Fe}^{+3} \#$ \\
\hline Norm. Harzburgite & $\mathrm{A}_{1}^{*}$ & 0.265 & 0.65 & - & 0.015 \\
\hline Norm. Harzburgite & $\mathrm{K}_{17}$ & 0.361 & 0.57 & - & 0.014 \\
\hline Norm. Harzburgite & $\mathrm{K}_{17}$ & 0.392 & 0.59 & 0.11 & 0.015 \\
\hline Norm. Harzburgite & $\mathrm{R}_{1}$ & 0.272 & 0.59 & 0.06 & 0.015 \\
\hline Norm. Harzburgite & $\mathrm{R}_{1}$ & 0.250 & 0.59 & 0.06 & - \\
\hline Norm. Harzburgite & $\mathrm{V}_{4}^{*}$ & 0.159 & 0.52 & 0.15 & - \\
\hline Norm. Harzburgite & $\mathrm{V}_{4}^{*}$ & 0.207 & 0.52 & 0.12 & - \\
\hline Norm. Harzburgite & $\mathrm{V}_{5}$ & 0.399 & 0.73 & 0.11 & 0.001 \\
\hline Trans. Harzburgite & $\mathrm{A}_{3}$ & 0.564 & 0.71 & 0.06 & 0.013 \\
\hline Trans. Harzburgite & $\mathrm{A}_{3}$ & 0.589 & 0.69 & 0.04 & 0.002 \\
\hline Trans. Harzburgite & $\mathrm{A}_{3}$ & 0.451 & 0.68 & 0.20 & 0.009 \\
\hline Trans. Harzburgite & $\mathrm{K}_{15}$ & 0.773 & 0.74 & 0.21 & - \\
\hline Trans. Harzburgite & $\mathrm{K}_{15}$ & 0.715 & 0.73 & 0.27 & 0.014 \\
\hline Trans. Harzburgite & $\mathrm{K}_{15}$ & 0.739 & 0.74 & 0.52 & 0.004 \\
\hline Trans. Harzburgite & $\mathrm{K}_{15}$ & 0.692 & 0.74 & - & 0.005 \\
\hline Trans. Harzburgite & $\mathrm{V}_{2}$ & 0.588 & 0.71 & 0.47 & 0.016 \\
\hline Trans. Harzburgite & $\mathrm{V}_{2}$ & 0.427 & 0.71 & 0.07 & 0.012 \\
\hline Coarse-grained Dunite & $\mathrm{A}_{7}$ & 0.544 & 0.72 & 0.05 & 0.007 \\
\hline Coarse-grained Dunite & $\mathrm{A}_{7}$ & 0.618 & 0.74 & 0.15 & 0.020 \\
\hline Coarse-grained Dunite & $\mathrm{A}_{7}$ & 0.595 & 0.71 & 0.16 & 0.009 \\
\hline Coarse-grained Dunite & $\mathrm{K}_{14}$ & 0.651 & 0.77 & 0.05 & 0.015 \\
\hline Coarse-grained Dunite & $\mathrm{K}_{14}$ & 0.691 & 0.80 & 0.44 & 0.021 \\
\hline Coarse-grained Dunite & $\mathrm{K}_{14}$ & 0.549 & 0.81 & 0.26 & 0.032 \\
\hline Coarse-grained Dunite & $\mathrm{K}_{14}$ & 0.664 & 0.82 & 0.36 & - \\
\hline Coarse-grained Dunite & $\mathrm{V}_{3}$ & 0.649 & 0.75 & 0.31 & 0.052 \\
\hline Coarse-grained Dunite & $\mathrm{V}_{3}$ & 0.587 & 0.72 & 0.38 & 0.049 \\
\hline Coarse-grained Dunite & $\mathrm{V}_{3}$ & 0.551 & 0.72 & 0.04 & 0.090 \\
\hline Fine-grained Dunite & $\mathrm{V}_{8}$ & 0.687 & 0.82 & 0.07 & 0.002 \\
\hline Fine-grained Dunite & $\mathrm{V}_{8}$ & 0.690 & 0.79 & 0.14 & 0.024 \\
\hline Fine-grained Dunite & $\mathrm{V}_{8}$ & 0.666 & 0.82 & 0.53 & 0.030 \\
\hline Fine-grained Dunite & $\mathrm{V}_{8}$ & 0.729 & 0.83 & 0.31 & - \\
\hline Fine-grained Dunite & $\mathrm{V}_{8}$ & 0.726 & 0.83 & 0.39 & 0.015 \\
\hline Fine-grained Dunite & $\mathrm{X}_{3}$ & 0.720 & 0.77 & 0.12 & 0.032 \\
\hline Fine-grained Dunite & $\mathrm{X}_{3}$ & 0.710 & 0.79 & 0.43 & 0.008 \\
\hline Fine-grained Dunite & $\mathrm{X}_{3}$ & 0.720 & 0.78 & 0.27 & 0.003 \\
\hline
\end{tabular}

$-:$ not detected, ${ }^{*}$ : granular normal harzburgite 
and dead-time $40 \%$. The ZAF correction was employed. Synthetic oxides and natural minerals were used as standards. Detection limits of $\sim 0.1 \%$ and accuracies better than $5 \%$ were achieved. The proportion of $\mathrm{Fe}^{3+}$ in chromian spinel was calculated assuming ideal spinel stoichiometry $\left(\mathrm{AB}_{2} \mathrm{O}_{4}\right)$. Selected analyses of chromian spinel from the studied peridotites are listed in Tab. 2.

Tab. 2 Representative chromian spinel analyses from the studied peridotites

\begin{tabular}{|c|c|c|c|c|c|c|c|c|c|c|c|c|c|}
\hline \multirow{3}{*}{$\begin{array}{l}\text { Peridotite } \\
\text { Texture } \\
\text { Sample }\end{array}$} & \multicolumn{13}{|c|}{ Normal Harzburgite } \\
\hline & \multicolumn{6}{|c|}{ Granular } & \multicolumn{7}{|c|}{ Porphyroclastic } \\
\hline & $\mathrm{E}_{1}$ & $\mathrm{E}_{1}$ & $\mathrm{~V}_{4}$ & $\mathrm{~V}_{4}$ & $\mathrm{~V}_{4}$ & $\mathrm{VM}_{74}$ & $A_{1}$ & $\mathrm{~A}_{1}$ & $\mathrm{~A}_{5}$ & $\mathrm{~A}_{5}$ & $\mathrm{~A}_{5}$ & $\mathrm{~K}_{17}$ & $\mathrm{R}_{2}$ \\
\hline Analysis (wt. \%) & 2 & 4 & 1 & 2 & 3 & 4 & 1 & 2 & 1 & 3 & 4 & 2 & 3 \\
\hline $\mathrm{SiO}_{2}$ & 0.94 & - & - & 0.15 & - & 0.17 & 0.37 & - & 0.35 & - & 0.06 & - & 0.91 \\
\hline $\mathrm{TiO}_{2}$ & 0.09 & 0.11 & 0.15 & - & - & 0.48 & 0.38 & 0.23 & 0.26 & - & 0.18 & - & 0.06 \\
\hline $\mathrm{Al}_{2} \mathrm{O}_{3}$ & 25.26 & 25.25 & 26.96 & 28.06 & 30.83 & 25.39 & 19.47 & 18.71 & 20.38 & 21.06 & 18.27 & 23.64 & 19.99 \\
\hline $\mathrm{Cr}_{2} \mathrm{O}_{3}$ & 43.14 & 44.84 & 44.09 & 42.33 & 40.63 & 43.79 & 47.46 & 49.71 & 49.12 & 48.27 & 51.97 & 46.40 & 48.60 \\
\hline $\mathrm{FeO}_{\mathrm{t}}$ & 15.49 & 16.67 & 13.93 & 16.66 & 15.36 & 16.06 & 19.34 & 19.47 & 18.61 & 18.98 & 20.00 & 18.91 & 19.34 \\
\hline $\mathrm{MnO}$ & 0.17 & - & 0.28 & - & - & - & 1.06 & 0.75 & - & - & 0.03 & - & 0.82 \\
\hline $\mathrm{MgO}$ & 14.25 & 14.68 & 14.18 & 12.99 & 13.24 & 14.30 & 11.10 & 10.83 & 10.95 & 10.89 & 10.01 & 11.47 & 10.55 \\
\hline $\mathrm{CaO}$ & - & - & - & - & 0.42 & 0.06 & - & 0.21 & - & - & - & - & - \\
\hline Total & 99.34 & 101.55 & 99.59 & 100.19 & 100.48 & 100.25 & 99.18 & 99.91 & 99.67 & 99.20 & 100.52 & 100.42 & 100.27 \\
\hline \multicolumn{14}{|l|}{ apfu } \\
\hline $\mathrm{Si}$ & 0.228 & - & - & 0.036 & - & 0.041 & 0.094 & - & 0.088 & - & 0.015 & - & 0.228 \\
\hline $\mathrm{Ti}$ & 0.016 & 0.020 & 0.027 & - & - & 0.087 & 0.073 & 0.044 & 0.049 & - & 0.034 & - & 0.011 \\
\hline $\mathrm{Al}$ & 7.202 & 7.111 & 7.627 & 7.893 & 8.533 & 7.185 & 5.840 & 5.611 & 6.035 & 6.270 & 5.465 & 6.867 & 5.909 \\
\hline $\mathrm{Cr}$ & 8.248 & 8.468 & 8.364 & 7.984 & 7.541 & 8.310 & 9.546 & 9.997 & 9.754 & 9.636 & 10.424 & 9.038 & 9.634 \\
\hline $\mathrm{Fe}^{3+}$ & 0.306 & 0.401 & - & 0.087 & - & 0.377 & 0.447 & 0.348 & 0.074 & 0.094 & 0.062 & 0.095 & 0.218 \\
\hline $\mathrm{Fe}^{2+}$ & 2.830 & 2.930 & 2.820 & 3.242 & 3.140 & 2.850 & 3.670 & 3.800 & 3.840 & 3.920 & 4.190 & 3.810 & 3.840 \\
\hline $\mathrm{Mn}$ & 0.035 & - & 0.057 & - & - & - & 0.229 & 0.162 & - & - & 0.006 & - & 0.174 \\
\hline $\mathrm{Mg}$ & 5.143 & 5.234 & 5.078 & 4.625 & 4.639 & 5.123 & 4.215 & 4.111 & 4.105 & 4.104 & 3.790 & 4.218 & 3.948 \\
\hline $\mathrm{Ca}$ & - & - & - & - & 0.106 & 0.015 & - & 0.057 & - & - & - & - & - \\
\hline$\Sigma$ & 24.008 & 24.164 & 23.955 & 23.867 & 23.959 & 23.988 & 24.114 & 24.130 & 23.945 & 24.024 & 23.986 & 24.028 & 23.962 \\
\hline $\mathrm{Cr} \#$ & 0.53 & 0.54 & 0.52 & 0.50 & 0.47 & 0.54 & 0.62 & 0.64 & 0.62 & 0.61 & 0.66 & 0.57 & 0.62 \\
\hline Mg\# & 0.64 & 0.64 & 0.64 & 0.58 & 0.60 & 0.64 & 0.53 & 0.52 & 0.52 & 0.51 & 0.47 & 0.53 & 0.51 \\
\hline Peridotite & \multicolumn{13}{|c|}{ Transitional Harzburgite } \\
\hline Sample & \multicolumn{3}{|r|}{$\mathrm{A}_{3}$} & $\mathrm{~A}_{3}$ & \multicolumn{2}{|c|}{$\mathrm{A}_{3}$} & $\mathrm{~K}_{15}$ & \multicolumn{2}{|l|}{$\mathrm{K}_{15}$} & $\mathrm{~V}_{2}$ & $\mathrm{~V}_{2}$ & \multicolumn{2}{|r|}{$\mathrm{V}_{2}$} \\
\hline Analysis (wt. \%) & \multicolumn{3}{|r|}{2} & 3 & \multicolumn{2}{|c|}{4} & 3 & \multicolumn{2}{|l|}{4} & 1 & 2 & \multicolumn{2}{|r|}{3} \\
\hline $\mathrm{SiO}_{2}$ & \multicolumn{3}{|r|}{-} & 0.42 & \multicolumn{2}{|c|}{-} & - & 0.19 & & - & - & & - \\
\hline $\mathrm{TiO}_{2}$ & 0.11 & & 0.06 & 0.04 & & 0.20 & 0.52 & - & & 0.47 & 0.36 & & 0.07 \\
\hline $\mathrm{Al}_{2} \mathrm{O}_{3}$ & 16.59 & & 4.80 & 16.4 & & 6.93 & 13.67 & 13.53 & & 14.76 & 15.11 & & 15.30 \\
\hline $\mathrm{Cr}_{2} \mathrm{O}_{3}$ & 53.65 & & 5.07 & 53.78 & & 2.57 & 56.58 & 56.52 & & 55.04 & 54.68 & & 54.81 \\
\hline $\mathrm{FeO}_{\mathrm{t}}$ & 18.02 & & 9.64 & 19.28 & & 8.85 & 18.76 & 19.55 & & 19.80 & 19.47 & & 18.66 \\
\hline $\mathrm{MnO}$ & 0.47 & & - & 0.34 & & - & - & 0.25 & & - & - & & - \\
\hline $\mathrm{MgO}$ & 10.27 & & 0.17 & 9.83 & & 0.73 & 10.16 & 9.52 & & 10.57 & 10.91 & & 11.04 \\
\hline Total & 99.11 & & 9.74 & 100.09 & & 9.28 & 99.69 & 99.56 & & 100.64 & 100.76 & & 99.88 \\
\hline apfu & & & & & & & & & & & & & \\
\hline $\mathrm{Si}$ & - & & - & 0.108 & & - & - & 0.050 & & - & - & & - \\
\hline $\mathrm{Ti}$ & 0.021 & & 0.012 & 0.008 & & 0.039 & 0.102 & - & & 0.091 & 0.069 & & 0.014 \\
\hline $\mathrm{Al}$ & 5.046 & & 4.516 & 4.955 & & 5.131 & 4.192 & 4.177 & & 4.472 & 4.562 & & 4.642 \\
\hline $\mathrm{Cr}$ & 10.943 & & 1.269 & 10.895 & & 0.685 & 11.636 & 11.700 & & 11.182 & 11.070 & & 11.151 \\
\hline $\mathrm{Fe}^{3+}$ & - & & 0.203 & 0.034 & & 0.145 & - & 0.073 & & 0.255 & 0.299 & & 0.193 \\
\hline $\mathrm{Fe}^{2+}$ & 3.900 & & 4.050 & 4.100 & & 3.910 & 4.020 & 4.210 & & 4.010 & 3.880 & & 3.830 \\
\hline $\mathrm{Mn}$ & 0.103 & & - & 0.074 & & - & - & 0.056 & & - & - & & - \\
\hline $\mathrm{Mg}$ & 3.954 & & 3.929 & 3.759 & & 4.117 & 3.944 & 3.720 & & 4.054 & 4.169 & & 4.240 \\
\hline$\Sigma$ & 23.957 & & 3.979 & 23.933 & & 4.027 & 23.964 & 23.986 & & 24.064 & 24.049 & & 24.070 \\
\hline $\mathrm{Cr} \#$ & 0.68 & & 0.71 & 0.69 & & 0.68 & 0.74 & 0.74 & & 0.71 & 0.71 & & 0.71 \\
\hline Mg\# & 0.50 & & 0.49 & 0.48 & & 0.51 & 0.50 & 0.47 & & 0.50 & 052 & & 0.53 \\
\hline
\end{tabular}

-: not detected, $\mathrm{Cr} \#: \mathrm{Cr} /(\mathrm{Cr}+\mathrm{Al}), \mathrm{Mg} \#: \mathrm{Mg} /\left(\mathrm{Mg}+\mathrm{Fe}^{2+}\right)$ 
Tab. 2 (continued)

\begin{tabular}{|c|c|c|c|c|c|c|c|c|c|c|c|c|c|}
\hline \multirow{3}{*}{$\begin{array}{l}\text { Peridotite } \\
\text { Sample } \\
\text { Analysis (wt. \%) } \\
\end{array}$} & \multicolumn{6}{|c|}{ Coarse-grained Dunite } & \multicolumn{7}{|c|}{ Fine-grained Dunite } \\
\hline & $\mathrm{A}_{7}$ & $\mathrm{~A}_{7}$ & $\mathrm{~A}_{7}$ & $\mathrm{~K}_{14}$ & $\mathrm{~K}_{14}$ & $\mathrm{~K}_{14}$ & $\mathrm{~V}_{1}$ & $\mathrm{~V}_{1}$ & $\mathrm{~V}_{1}$ & $\mathrm{X}_{3}$ & $\mathrm{X}_{3}$ & $\mathrm{X}_{3}$ & $\mathrm{X}_{3}$ \\
\hline & 3 & 4 & 5 & 1 & 4 & 5 & 4 & 8 & 9 & 2 & 3 & 6 & 7 \\
\hline $\mathrm{SiO}_{2}$ & 0.15 & 0.38 & - & - & - & 0.11 & - & - & - & - & - & - & - \\
\hline $\mathrm{TiO}_{2}$ & 0.05 & 0.15 & 0.16 & 0.21 & 0.44 & 0.26 & 0.17 & 0.18 & 0.17 & 0.20 & 0.12 & 0.41 & 0.27 \\
\hline $\mathrm{Al}_{2} \mathrm{O}_{3}$ & 14.53 & 13.16 & 15.01 & 9.86 & 10.11 & 9.24 & 11.58 & 11.98 & 12.14 & 11.27 & 12.25 & 11.96 & 11.16 \\
\hline $\mathrm{Cr}_{2} \mathrm{O}_{3}$ & 56.47 & 56.33 & 55.89 & 59.27 & 58.50 & 58.80 & 60.88 & 59.55 & 58.72 & 60.01 & 60.30 & 60.51 & 60.65 \\
\hline $\mathrm{FeO}_{\mathrm{t}}$ & 19.15 & 18.66 & 19.29 & 21.49 & 21.26 & 21.60 & 14.31 & 15.05 & 14.82 & 14.37 & 13.09 & 13.75 & 14.54 \\
\hline $\mathrm{MnO}$ & - & - & - & 0.43 & - & - & 0.18 & 0.19 & 0.22 & 0.30 & - & - & - \\
\hline $\mathrm{MgO}$ & 10.51 & 11.19 & 10.60 & 8.97 & 9.19 & 9.58 & 13.88 & 13.71 & 13.98 & 13.40 & 13.63 & 13.61 & 12.53 \\
\hline $\mathrm{CaO}$ & - & 0.11 & - & - & - & - & - & - & - & - & - & - & - \\
\hline Total & 100.86 & 99.98 & 100.95 & 100.23 & 99.50 & 99.59 & 101.00 & 100.66 & 100.05 & 99.55 & 99.39 & 100.24 & 99.15 \\
\hline \multicolumn{14}{|l|}{ apfu } \\
\hline $\mathrm{Si}$ & 0.038 & 0.098 & - & - & - & 0.030 & - & - & - & - & - & - & - \\
\hline $\mathrm{Ti}$ & 0.010 & 0.029 & 0.031 & 0.042 & 0.089 & 0.053 & 0.033 & 0.034 & 0.033 & 0.039 & 0.023 & 0.079 & 0.053 \\
\hline $\mathrm{Al}$ & 4.391 & 4.017 & 4.526 & 3.103 & 3.191 & 2.926 & 3.473 & 3.587 & 3.646 & 3.422 & 3.704 & 3.587 & 3.422 \\
\hline $\mathrm{Cr}$ & 11.443 & 11.531 & 11.300 & 12.509 & 12.383 & 12.485 & 12.250 & 11.955 & 11.826 & 12.219 & 12.226 & 12.170 & 12.471 \\
\hline $\mathrm{Fe}^{3+}$ & 0.118 & 0.325 & 0.143 & 0.346 & 0.337 & 0.506 & 0.244 & 0.424 & 0.495 & 0.320 & 0.047 & 0.164 & 0.054 \\
\hline $\mathrm{Fe}^{2+}$ & 3.990 & 3.720 & 3.990 & 4.460 & 4.430 & 4.350 & 2.801 & 2.780 & 2.670 & 2.780 & 2.760 & 2.770 & 3.110 \\
\hline $\mathrm{Mn}$ & - & - & - & 0.097 & - & - & 0.039 & 0.041 & 0.048 & 0.066 & - & - & - \\
\hline $\mathrm{Mg}$ & 4.020 & 4.324 & 4.046 & 3.574 & 3.672 & 3.840 & 5.266 & 5.196 & 5.315 & 5.151 & 5.217 & 5.167 & 4.864 \\
\hline $\mathrm{Ca}$ & - & 0.031 & - & - & - & - & - & - & - & - & - & - & - \\
\hline$\Sigma$ & 24.010 & 24.075 & 24.036 & 24.131 & 24.102 & 24.190 & 24.106 & 24.017 & 24.033 & 23.997 & 23.977 & 23.937 & 23.974 \\
\hline $\mathrm{Cr} \#$ & 0.72 & 0.74 & 0.71 & 0.80 & 0.80 & 0.81 & 0.78 & 0.77 & 0.76 & 0.78 & 0.77 & 0.77 & 0.78 \\
\hline $\mathrm{Mg \#}$ & 0.50 & 0.54 & 0.50 & 0.45 & 0.45 & 0.47 & 0.63 & 0.65 & 0.67 & 0.65 & 0.65 & 0.65 & 0.61 \\
\hline
\end{tabular}

-: not detected, $\mathrm{Cr} \#: \mathrm{Cr} /(\mathrm{Cr}+\mathrm{Al}), \mathrm{Mg} \#: \mathrm{Mg} /\left(\mathrm{Mg}+\mathrm{Fe}^{2+}\right)$

Whole-rock REE analyses were performed at ActLabs, Ontario, Canada, using a Perkin Elmer Sciex ELAN 9000 Inductively Coupled Plasma-Mass Spectrometer (ICP-MS). Crushed dry samples were acid-digested for analysis by ICP-MS, by the methods of Bailey et al. (1993) and Lewis et al. (1997). $200 \mathrm{mg}$ of the dried sample was weighted into a PTFE (polytetrafluoroethylene) beaker, and moistened with $2 \mathrm{ml}$ of $18 \mathrm{M} \Omega$ water; $3 \mathrm{ml}$ of $40 \% \mathrm{v} / \mathrm{v} \mathrm{HF}$ and $2 \mathrm{ml}$ of concentrated $\mathrm{HNO}_{3}$

Tab. 3 Whole-rock REE data of normal and transitional harzburgite from Vourinos

\begin{tabular}{lcc}
\hline Peridotite & Normal Harzburgite & Transitional Harzburgite \\
Sample & $\mathrm{V}_{6}$ & $\mathrm{~V}_{2}$ \\
\hline $\mathrm{La}$ & 0.08 & 0.26 \\
$\mathrm{Ce}$ & 0.16 & 0.54 \\
$\mathrm{Pr}$ & 0.01 & 0.04 \\
$\mathrm{Nd}$ & $<0.05$ & 0.11 \\
$\mathrm{Sm}$ & 0.01 & 0.02 \\
$\mathrm{Eu}$ & $<0.005$ & $<0.005$ \\
$\mathrm{Gd}$ & $<0.01$ & 0.01 \\
$\mathrm{~Tb}$ & $<0.01$ & $<0.01$ \\
$\mathrm{Dy}$ & $<0.01$ & 0.02 \\
$\mathrm{Ho}$ & $<0.01$ & $<0.01$ \\
$\mathrm{Er}$ & 0.01 & 0.01 \\
$\mathrm{Tm}$ & $<0.005$ & $<0.005$ \\
$\mathrm{Yb}$ & 0.02 & 0.02 \\
$\mathrm{Lu}$ & 0.004 & 0.003 \\
\hline
\end{tabular}

were added. The beaker was then placed on a hot plate at $210{ }^{\circ} \mathrm{C}$ and the solution was evaporated just to dryness before being removed from the hotplate. $30 \mathrm{ml}$ of $5 \%$ $\mathrm{v} / \mathrm{v} \mathrm{HNO}_{3}$ was added to the cooled beaker and the beaker returned to the hotplate to dissolve the cake. The sample was made up to $100 \mathrm{ml}$ with $5 \% \mathrm{v} / \mathrm{v} \mathrm{HNO}_{3}$ after the addition of an internal standard. The internal standard was used to compensate for any analytical drift and matrix suppression effects. Calibration of the ICP-MS was via international rock standards with the addition of an inhouse peridotite standard. These standards and analytical blanks were prepared by the same technique as the samples. The composition of the reference samples was analyzed as unknown during the same analytical runs as Vourinos peridotite samples. For REE reproducibility of these reference samples was generally better than $5 \%$. Detection limits were: $0.05 \mathrm{ppm}$ for $\mathrm{La}, \mathrm{Ce}$, and $\mathrm{Nd}, 0.01$ ppm for Pr, Sm, Gd, Tb, Dy, Ho, Er and Yb, 0.005 ppm for $\mathrm{Eu}$ and $\mathrm{Tm}$ and $0.002 \mathrm{ppm}$ for Lu. Two representative bulk-rock REE analyses of the investigated peridotites are listed in Tab. 3.

\section{Field relations}

Deformed massive harzburgite is the dominant peridotite type in the Vourinos mantle suite accompanied by minor 
dunite. Harzburgite commonly contains blocky-shaped pyroxene. Pyroxene lineation/elongation is frequently cut by diffusely distributed spinel (Fig. 2a). Thick mylonitic zones crop out within the harzburgite at the northern part of the Ophiolite Complex. The dunite bodies are present in various modes of occurrence (e.g., pods, lenses) and range in size from a few $\mathrm{m}$ up to a few $\mathrm{km}$ (e.g., Xerolivado district). The contacts between harzburgite and dunite are transitional at the meter- to tens of meters scale and are difficult to be mapped in the field. Dunite deformational layers are intercalated with harzburgite. Moreover dunite commonly hosts chromitite bodies. Frequently dunite and chromitite are "entrapped" in shear zones. In the vicinity of the chromitites dunite commonly turns to be fine-grained. Rarely small dunite "blocks" can be recognized within harzburgite (Fig. 2b), thus suggesting a replacement relation between these two peridotite types.

\section{Petrography}

The peridotites hosted in the Vourinos mantle suite are harzburgites and dunites. Two varieties of harzburgites are distinguished: normal and transitional. This division is based on the distinct petrographic features. Normal harzburgite is granular to (framed) porphyroclastic (Fig. 2c) in texture. Main constituent minerals are olivine (70-83 vol. \%), orthopyroxene (15-28 vol. \%), clinopyroxene $(<5$ vol. $\%)$ and chromian spinel $(\leq 1 \mathrm{vol}$. $\%)$. Olivine-orthopyroxene boundaries are irregular and both phases display deformational characteristics, such as anomalous extinction band configurations. Interstitial chromian spinel is brown to reddish under the microscope and is mostly irregularly shaped, showing lobate boundaries ("vermicular" spinel, Fig. 2d). Sporadically anhedral intergrowths of orthopyroxene and chromian spinel can be recognized in the most clinopyroxene-rich samples. Transitional (/olivine-rich) harzburgite is porphyroclastic in texture, containing olivine (85-87 vol. \%), orthopyroxene (12-14 vol. \%), chromian spinel (1-3 vol. \%) and occasionally traces of clinopyroxene. Olivine crystals have irregular shapes with sinuous boundaries, commonly elongated showing undulose extinction. Orthopyroxenes exhibit concave boundaries filled with olivine and spinel neoblasts (Fig. 2e). Subhedral to euhedral chromian spinel is present either interstitially to mantle phases or in the form of inclusions in orthopyroxene porphyroclasts (Fig. 2e). Orthopyroxene crystals also show undulose extinction, kink bands and clinopyroxene exsolution lamellae (Fig. 2f). Although all harzburgitic rocks are intensely deformed, they may contain unstrained phases such as olivine and minor clinopyroxene (the latter only in normal harzburgite), mainly in the form of inclusions in orthopyroxene porphyroclasts and infrequently interstitially to mantle phases.

The degree of serpentinization in all the studied harzburgitic samples does not exceed 20 vol. \%. Replacement to serpentine affected both olivine and pyroxene, leading to the local formation of a mesh and bastite texture, respectively. Sometimes chromian spinel grains may be partially altered to ferritchromite and chromian chlorite, as a result of metamorphic alteration (Grieco and Merlini 2011). Tremolite also occurs as an accessory secondary phase.

Dunite is variably textured, ranging from coarse- to fine-grained. Main constituent minerals in both dunite types are olivine (90-95 vol. \%), accompanied by orthopyroxene $(\leq 5$ vol. $\%)$ and dark reddish chromian spinel ( $\leq 5$ vol. \%). Coarse-grained dunite shows equigranular to mylonitic texture. It is composed of sizeable olivine crystals (up to a few $\mathrm{mm}$ across), exhibiting strong deformational features. In equigranular dunite olivine is polygonal in shape, displaying many $120^{\circ}$ triple grain junctions (Fig. 2g) indicating recrystallization, and kink bands. Mylonitized dunite contains elongated olivine grains, showing intense undulose extinction. Olivine porphyroclasts are surrounded by a recrystallized matrix of tiny olivine neoblasts. In some mylonitized dunite samples elongated tremolite crystals may occur. Coarsegrained dunite is characterized by euhedral chromian spinel, frequently embodied within the olivine megacrysts. Fine-grained dunite shows mosaic texture (Fig. 2h) and is composed of small olivine grains and euhedral chromian spinel, commonly found at the triple junctions of annealed olivine crystals. It is worthy to mention that the amount of chromian spinel is commonly higher in fine-grained dunite compared to that in coarse-grained one ( 5 vol. $\%$ vs. $3-5$ vol. $\%$, respectively).

\section{Morphology of chromian spinel}

To define chromian spinel morphology quantitatively the so-called "degree of roundness" (DR\#, according to

Fig. 2 Photographs of mantle peridotites from the Vourinos Ophiolite Complex. a - Diffusely distributed spinel in harzburgite interrupting pyroxene lineation. b - Dunite enclosed in harzburgite (contact being marked by the black dashed line). Photomicrographs of mantle peridotites from the Vourinos Ophiolite Complex: c - Porphyroclastic texture in normal harzburgite [crossed nicols (XPL)]. d - Anhedral ("vermicular") chromian spinel in normal harzburgite [plane polarized light (PPL)]. e - Orthopyroxene porphyroclast with euhedral chromian spinel inclusions surrounded by olivine neoblasts (XPL). f - Exsolution lamellae of clinopyroxene in an orthopyroxene porphyroclast from transitional harzburgite [back scattered electron image (BSE)]. g - Annealing olivine texture in coarse-grained dunite (XPL). $\mathbf{h}$ - Fine-grained dunite exhibiting mosaic texture (XPL). Abbreviations: Sp - chromian spinel; Dn - dunite; Hz - harzburgite; Ol - olivine; Opx - orthopyroxene; Cpx - clinopyroxene. 

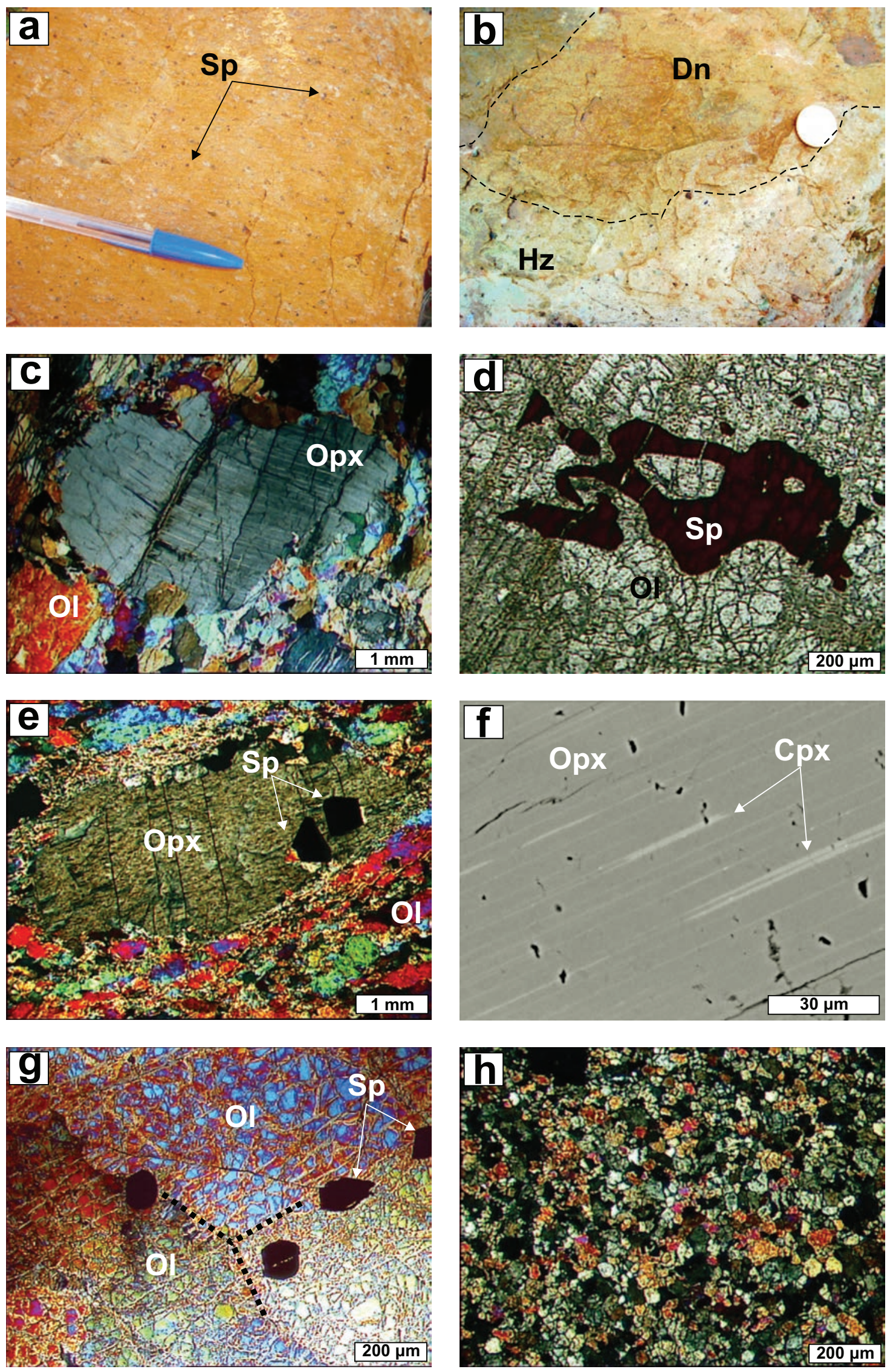
Matsumoto and Arai 2001) was calculated, according to the equation: $A /\left[(1 / 4 \pi) \times R^{2}\right]$, where $A$ and $R$ stand for area and circumference of chromian spinel grains, respectively. Measurement results are listed in Tab. 1.

It is expected that the DR\# is low $(<0.40)$ if the grain is irregularly shaped ("vermicular") and high (>0.60) if it is euhedral (Matsumoto and Arai 2001). Since the studied chromian spinels do not preserve any obvious stress-induced characteristics (e.g., elongation, disruption followed by rearrangement), which could have modified their original morphology, they can be used as key tools to help us understand the processes involved in the formation of the Vourinos mantle rocks. Chromian spinel crystals from the Vourinos peridotites show a wide range of DR\# values, varying between 0.16 and 0.77 . Chromian spinel has relatively high DR\# in dunite $(0.54-0.73)$ and low DR\# in normal harzburgite $(0.16-0.40)$. On the other hand, chromian spinel in transitional harzburgite shows a wide range of DR\# of 0.38 to 0.77 . Although it is harzburgitic rock it contains euhedral chromian spinel, which resembles the same mineral in dunite. This controversy implies the significance of this very rock type in the interpretation of the petrologic processes locally affecting the formation of the Vourinos peridotites.

\section{Chromian spinel chemistry}

Homogeneous opaque accessory chromian spinel occurs in all the investigated peridotite samples. Despite the effects of serpentinization, chromian spinel grains are generally unaltered, although the replacement of chromian spinel by ferritchromite has been reported by previous studies on the alteration of chromite from the Vourinos chromitites (Grieco and Merlini 2011). Therefore the unaltered nature is indicative of their primary origin.

Their $\mathrm{Cr} \#[\mathrm{Cr} /(\mathrm{Cr}+\mathrm{Al})]$ ranges from 0.47 to 0.84 and $\mathrm{Mg} \#\left[\mathrm{Mg} /\left(\mathrm{Mg}+\mathrm{Fe}^{2+}\right)\right]$ from 0.45 to 0.66 (Fig. 3). The normal harzburgite contains chromian spinel with a wide range of $\mathrm{Cr} \#$ values (0.47-0.74), whereas the transitional harzburgite features chromian spinel with a more restricted range of $\mathrm{Cr} \#(0.68-0.74)$. Dunitic rocks contain chromian spinel with higher $\mathrm{Cr} \#(0.71-0.84)$.

Two compositional groups of chromian spinel in normal harzburgite can be distinguished in terms of $\mathrm{Cr} \#$ and $\mathrm{Mg \#}$ values (Fig. 3). The first includes chromian spinel with lower Cr\# (0.47-0.65) and higher Mg\# (0.57-0.64) in granular textured normal harzburgite and the second chromian spinel of higher $\mathrm{Cr} \#(0.57-0.74)$ and lower

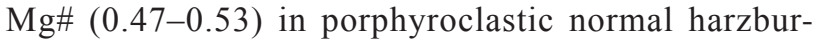
gite. The latter fall in the field of spinel from fore-arc peridotites, whereas chromian spinel compositions from granular normal harzburgite plot at the boundary between the fields of spinel from fore-arc peridotites (Ishii et al.
1992; Ohara and Ishii 1998) and modern abyssal peridotites (Dick and Bullen 1984; Juteau et al. 1990; Fig. 3). Moreover, chromian spinel from the transitional harzburgite plots in the field of spinels from fore-arc peridotites (Ishii et al. 1992; Ohara and Ishii 1998).

Chromian spinel in coarse-grained dunite has low $\mathrm{Mg} \#(0.45-0.55)$, whereas that in fine-grained dunite it is characterized by high $\mathrm{Mg} \#$ values $(0.59-0.66)$. On $\mathrm{Cr} \#$ vs. Mg\# plot, dunitic chromian spinel compositions form two clusters at the high-Cr\# end of the diagram (Fig. 3). Additionally, the composition of chromian spinel from fine-grained dunite is similar to that of spinels in equilibrium with magmas of boninitic affinity (Dick and Bullen 1984), whereas the composition of chromian spinel from coarse-grained dunite plots between the fields of spinel from boninites and fore-arc peridotites.

Chemistry of chromian spinel is related with morphology. The DR\# is positively correlated with $\mathrm{Cr} \#\left(r^{2}\right.$ : 0.79 , Fig. 4). In particular, there is a positive correlation between Cr\# and DR\# of chromian spinel from normal harzburgite $\left(r^{2}: 0.61\right)$ and dunite $\left(r^{2}: 0.70\right)$, but no correlation exists between $\mathrm{Cr} \#$ and $\mathrm{DR} \#$ of chromian spinel from transitional harzburgite $\left(r^{2}: 0.43\right)$ and the $\mathrm{Cr} \#$ values rise only gently with increasing DR\#. The DR\# seems to be independent of $\mathrm{TiO}_{2}$ or $\mathrm{Fe}^{3+} \#\left[\mathrm{Fe}^{3+} /\left(\mathrm{Fe}^{3+}+\mathrm{Cr}+\mathrm{Al}\right)\right]$. However, the range of $\mathrm{TiO}_{2}$ contents and $\mathrm{Fe}^{3+} \#$ in chromian spinel appears to be dependent on lithology, being relatively wider in dunitic spinel (Tab. 1).

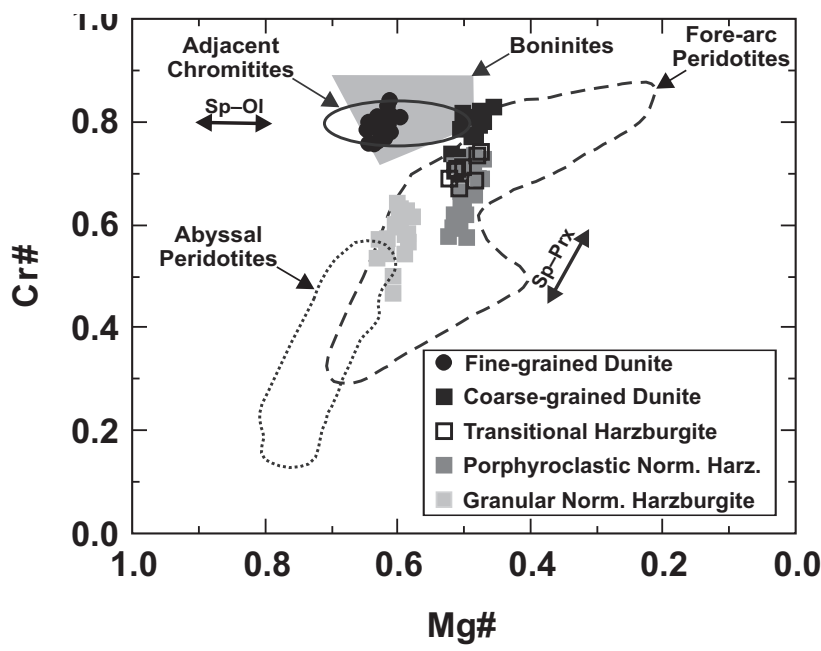

Fig. 3 Chromian spinel compositions from the Vourinos peridotites, in terms of $\mathrm{Cr} \#[\mathrm{Cr} /(\mathrm{Cr}+\mathrm{Al})]$ vs. $\mathrm{Mg} \#\left[\mathrm{Mg} /\left(\mathrm{Mg}+\mathrm{Fe}^{2+}\right]\right.$. Data for spinel in modern abyssal peridotites are from Dick and Bullen (1984) and Juteau et al. (1990). Field for spinel in boninites is taken from Dick and Bullen (1984). Data for spinel in fore-arc peridotites are from Ishii et al. (1992) and Ohara and Ishii (1998). The black thick line marks the composition of chromian spinel from the chromitites hosted in the studied peridotites given by Kapsiotis (2009). The double arrows marked $\mathrm{Sp}-\mathrm{Ol}$ and $\mathrm{Sp}-\mathrm{Prx}$ illustrate the trends of variation expected from subsolidus re-equilibration between spinel and olivine, and spinel and pyroxene, respectively (Bédard and Hébert 1998). 


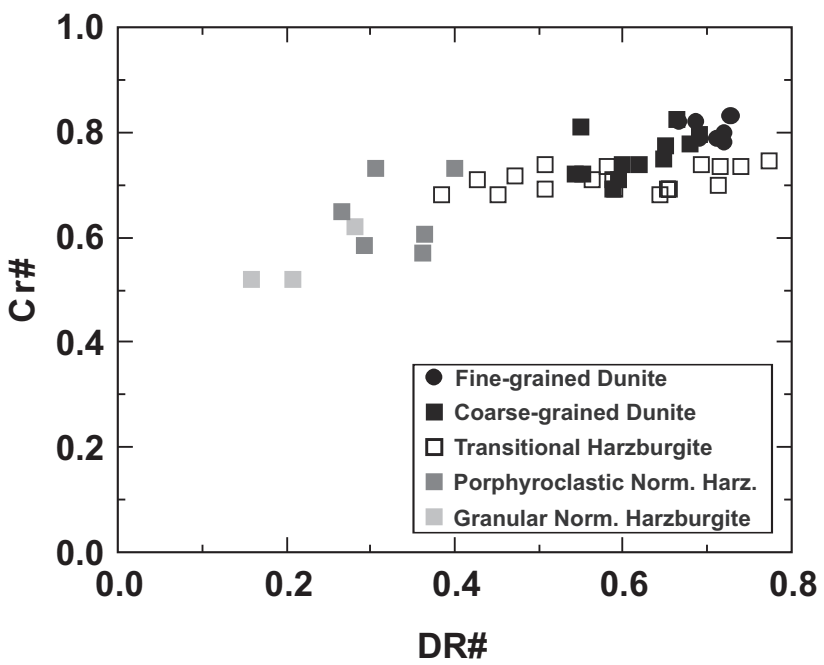

Fig. 4 Morphological and chemical variation of chromian spinel, in terms of $\mathrm{Cr} \#[\mathrm{Cr} /(\mathrm{Cr}+\mathrm{Al})]$ vs. DR\# (degree of roundness) plot.

\section{Whole-rock REE chemistry}

The peridotites are generally characterized by extremely low Rare Earth Elements (REE) concentrations. In fact, only the heaviest REE ( $\mathrm{Yb}$ and $\mathrm{Lu}$ ) were analyzed in most of the investigated peridotites, whereas the remaining REE were lower than the detection limits. Almost a complete range of REE was possible to detect only in two harzburgitic samples (from the Voidolakkos district) a porphyroclastic normal $\left(\mathrm{V}_{6}\right)$ and a transitional harzburgite $\left(\mathrm{V}_{2}\right)$. The REE contents range from 0.1 to 0.3 times the chondritic value, and chondrite-normalized REE patterns for both harzburgitic rock types are U-shaped, exhibiting positive MREE to HREE slopes and relative LREE enrichment $\left[(\mathrm{La} / \mathrm{Yb})_{\mathrm{N}}=6.86\right.$ and $22.28,(\mathrm{La} / \mathrm{Sm})_{\mathrm{N}}$ $=9.23$ and 15.00; Fig. 5]. Normal harzburgite has lower REE concentrations compared to transitional harzburgite.

Both samples are little affected by alteration processes [Loss on ignition (L.O.I.) < 3.7 wt. \%, Kapsiotis 2009], thus implying that their REE contents are most likely undisturbed. Furthermore, the obtained U-shaped REE patterns are comparable to those reported from more or less serpentinized ultramafites (e.g., De Hoog et al. 2008).

\section{Discussion}

\subsection{Interpretation of textural and bulk-rock REE data}

The petrographic data show that the granular texture in normal harzburgite is a primary mantle feature, which indicates deformation at near-solidus or hyper-solidus temperatures $\left(1200^{\circ} \mathrm{C}\right.$; Nicolas 1989). In particular, the blocky-shaped orthopyroxene in normal harzburgite in the northern regions of the Ophiolite Complex (Voidolakkos and Rizo) is thought to represent a "mantle" fabric originating from asthenospheric flow in an upwelling mantle diapir (Rassios et al. 1994; Rassios and Moores 2006; Rassios and Dilek 2009). This early high-temperature fabric reflects the strain imposed on mantle rocks shortly after, and possibly concurrent, to partial melting (Rassios et al. 1994). On the other hand, the porphyroclastic texture in normal and transitional harzburgite (as well as the equigranular and mylonitic texture in dunite) indicates lower temperature ductile flow $\left(700-900^{\circ} \mathrm{C}\right)$, presumably representing deformation within relatively cold lithospheric mantle (e.g., Dijkstra et al. 2002; Michibayashi 2009). Moreover, these rocks commonly contain deformed orthopyroxene crystals that display concave grain boundaries filled with olivine, suggesting melt-rock reactions that consumed pyroxene and precipitated olivine (e.g., Kelemen et al. 1995).

On the basis of petrological data the Vourinos peridotites have traditionally been viewed as refractory residues produced by multi-stage partial melting of an initially undepleted mantle source (e.g., Beccaluva et al. 2005; Saccani et al. 2008). However, this interpretation does not seem to explain sufficiently the formation of the harzburgites in the Voidolakkos district. In particular, the low MREE and HREE contents of the Vourinos harzburgites compared to undepleted mantle and Alpine lherzolites, confirm that they represent mantle residues (e.g., Godard et al. 2000; Takazawa et al. 2003; Zhou et al. 2005) after more than one melting episodes (e.g., Beccaluva et al. 2005; Saccani et al. 2008; Fig. 5), since the melting degree needed to cause such extreme

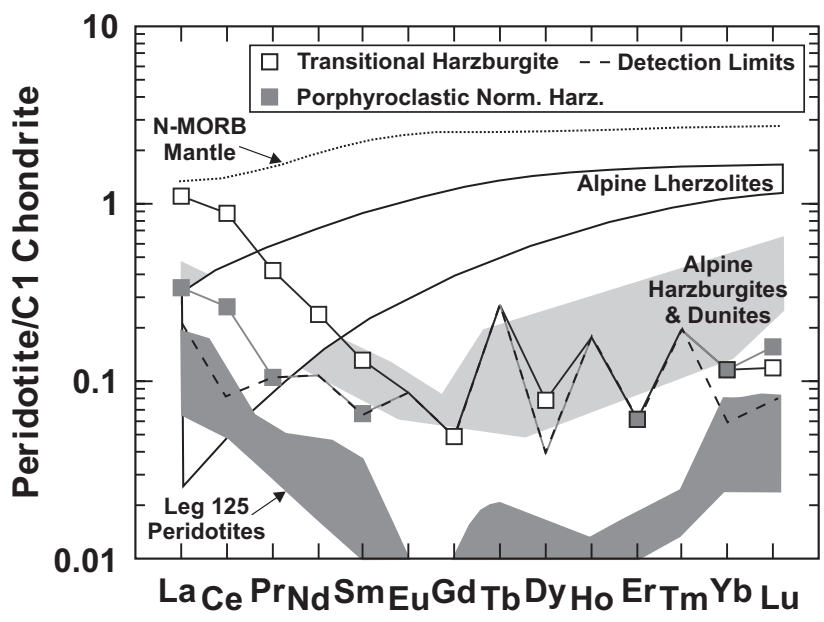

Fig. 5 Whole-rock C1 chondrite-normalized (McDonough and Sun 1995) REE abundances of the investigated harzburgites. Alpine peridotites fields are from Li (1992), the field of peridotites from Leg 125 is from Parkinson et al. (1992), N-MORB mantle REE composition is from McCulloch and Bennett (1994). 
MREE-HREE depletion during a single melting event is geologically unattainable (Arai 1994a). However, the relative enrichment of some of the Voidolakkos harzburgites in LREE contradicts the operation of partial melting processes on their own (Kapsiotis et al. 2009). The U-shaped REE patterns are rather attributable to interaction between an already depleted peridotite and hydrous boninitic melt (e.g., Kelemen et al. 1992; Suhr et al. 1998; Zhou et al. 2005; De Hoog et al. 2008; Uysal et al. 2012), as it is the case for Alpine harzburgites (Li 1992) and peridotites from Leg 125 (Parkinson et al. 1992; Fig. 5). It is likely that the added melt had an external mantle source since depleted harzburgites can only produce low-LREE liquids (De Hoog et al. 2008), which precludes any possibility for the trapped melt to have a residual origin.

The same metasomatic agent could have affected both normal and transitional harzburgite as is indicated by their parallel U-shaped normalized REE patterns. In addition, transitional harzburgite is characterized by total LREE abundances higher than in the normal harzburgite (e.g., Kapsiotis et al. 2009). Normally lower LREE abundances are expected in peridotites of more refractory nature. Such an inconsistency is commonly attributed to chromatographic effects during diffuse porous flow of LREE-enriched melts through (reactive) harzburgites, where the more incompatible elements travel faster through the melting column (Navon and Stopler 1987; $\mathrm{Xu}$ et al. 2003). It also provides evidence that the melt percolated through transitional harzburgite first and then proceeded to normal harzburgite. Boninite-harzburgite interaction did not significantly perturb the mineral modes or whole-rock compositions (cryptic metasomatism) perhaps due to low melt/rock ratio at that stage of diffuse porous melt flow through harzburgites. Based on pyroxene geothermometry data, Vils et al. (2005) also assumed an invasion of a mafic melt in the Vourinos harzburgites to having been responsible for a cryptic metasomatic event (Bizimis et al. 2000).

Since clinopyroxene is the main repository for REE in spinel peridotites (Wiechert et al. 1997) their bulkrock REE patterns should bear resemblance to those of clinopyroxene. LREE-enriched clinopyroxenes are commonly found in mantle peridotites and are interpreted as a result of metasomatism (e.g., Godard et al. 2000; Xu et al. 2003; Ntaflos et al. 2007; Tamura et al. 2008). However, the examined sample of normal harzburgite lacks clinopyroxene, whereas transitional harzburgite sample contains only traces of deformed residual clinopyroxene. Generally, clinopyroxene is only a minor constituent in the Vourinos harzburgitic rocks; therefore it is supposed that their local LREE enrichment may be due to the interstitial entrapment of LREE-enriched melts (Bizimis et al. 2000; Kapsiotis et al. 2009).

\subsection{Interpretation of chromian spinel data}

The composition of accessory spinel in peridotites is regarded as a useful tool for revealing melting processes in mantle (e.g., Okamura et al. 2006; Uysal et al. 2007). It is also known that $\mathrm{Al}$ content of spinel is sensitive to mantle melting processes and that systematically decreases with the degree of peridotite depletion (e.g., Zhou et al. 2005; Uysal et al. 2012). Based on this criterion it is deduced that the Vourinos peridotites (except for fine-grained dunite) were produced by variable degrees of mantle melting. The $\mathrm{Cr} \#$ is lower in chromian spinel from the harzburgitic rocks compared to that in chromian spinel from coarse-grained dunite; therefore the latter should represent a mantle residue resulting from higher melting degrees.

$\mathrm{The} \mathrm{Cr} \#$ and $\mathrm{Mg} \#$ of some anhedral chromian spinels from granular normal harzburgite falls on the intersection of the fields of spinels from modern abyssal and fore-arc peridotites (Fig. 3). The hybrid petrogenetic character of these chromian spinels indicates that granular textured normal harzburgite probably formed by a two-stage melting process in different geotectonic regimes.

Compared to chromian spinel from the porphyroclastic normal harzburgite, that from the granular normal harzburgite has higher $\mathrm{Mg} \#$. This difference may be attributed to distinct deformation processes by which the harzburgitic rocks have been affected. Deformation of porphyroclastic normal harzburgite under cold lithospheric conditions may have been responsible for the input of $\mathrm{Fe}^{2+}$ in chromian spinel structure thus lowering its Mg\# (Ozawa 1989). Additionally, the lower $\mathrm{Mg} \#$ values in chromian spinel from porphyroclastic normal harzburgite may be ascribed to spinel-pyroxene equilibration, which is also characterized by an increase of $\mathrm{Fe}^{2+}$ content in spinel (Bédard and Hébert 1998). Furthermore, according to Okamura et al. (2006) the low $\mathrm{Mg} \#$ of spinel from depleted harzburgite and dunite may have resulted from cooling exclusively in the fore-arc mantle wedge by $\mathrm{H}_{2} \mathrm{O}$ released from the subducted slab. Although deformation seems to have controled differences in chromian spinel composition, it is suggested that a combination of the above mentioned processes may account for the low $\mathrm{Mg} \#$ values of chromian spinel from porphyroclastic normal harzburgite, transitional harzburgite and coarse-grained dunite.

Chromian spinel from these three rock types plots in the field of spinel from fore-arc peridotites (Fig. 3), forming a continuous trend of negatively correlated $\mathrm{Cr} \#$ and $\mathrm{Mg} \#$ values, suggesting that these rocks were formed by different degrees of partial melting. This is in accordance with the commonly observed linear covariation between $\mathrm{Cr} \#$ and $\mathrm{Mg} \#$ in residual spinels from abyssal or arc peridotites (e.g., Ahmed et al. 2001; Zhou et al. 
2005). However, the systematic changes of chromian spinel morphology from normal harzburgite to coarsegrained dunite are not in favor of partial melting processes. Moreover, mantle peridotites containing spinels with high $\mathrm{Cr} \#(>0.70)$ are expected to derive from high degrees of partial melting yielding pyroxene-free dunites (Uysal et al. 2012). In contrast, some normal and transitional harzburgite samples contain chromian spinel with $\mathrm{Cr} \#>0.70$. This controversy combined with the presence of euhedral chromian spinel grains in transitional harzburgite and coarse-grained dunite, reflects probably an involvement of melt-rock reaction processes in their formation (Godard et al. 2008). The presence of $\mathrm{TiO}_{2}$ enriched chromian spinels in these peridotites also supports an influence by spinel addition processes. Normally, $\mathrm{Cr} \#$ in spinel is expected to increase, whereas $\mathrm{TiO}_{2}$ should decrease as the degree of peridotite depletion rises (e.g., Zhou et al. 2005; Uysal et al. 2007; Delavari et al. 2009).

Furthermore, the formation of dunite in many ophiolite mantle sections is thought to represent the result of interaction between infiltrating melts and peridotites, which leads to incongruent pyroxene dissolution and precipitation of olivine and spinel (e.g., Dai et al. 2011). The present data show that transitional harzburgite may represent the wall-rock of such an interaction zone and that coarse-grained dunite could have served as "channels" for melt percolation (e.g., Kelemen et al. 1995).

During mantle melting, related to melt-rock reaction, and the formation of olivine-rich residues, $\mathrm{Cr}$ behaves incompatibly, becoming sufficiently concentrated in the melt to crystallize podiform chromitites through melt-rock reaction and magma mixing (e.g., Matveev and Ballhaus 2002; O'Driscoll et al. 2012). Chromitite masses hosted in the studied peridotites have formed from influxes of boninite melt in the Vourinos depleted mantle (Kapsiotis 2009; Grammatikopoulos et al. 2011). Chromian spinel in fine-grained dunite bears resemblance in terms of $\mathrm{Cr} \#$ and $\mathrm{Mg} \#$ with the ore-hosted chromian spinel (Fig. 3). Since any effects of rock recrystallization and re-equilibration between spinel and olivine are expected to lower $\mathrm{Mg \#}$ in spinel (Bédard and Hébert 1998), a genetic linkage between chromitite and finegrained dunite must exist. It seems that after chromitite formation the volume of the melt decreased and started to crystallize solely olivine and minor chromian spinel, thus retaining $\mathrm{Cr} \#$ and $\mathrm{Mg} \#$ in chromian spinel at (nearly) the same values compared to those in chromian spinel from the neighboring chromitites, leading to the formation of fine-grained dunite. After fine-grained dunite formation, smaller volumes of melt could have impregnated the adjacent wall-rock peridotites and started modifying their accessory chromian spinels or even crystallizing new ones (in coarse-grained dunite and transitional harz- burgite). The $\mathrm{Cr} \#$ of the melt remained high because of combined volume decrease and selective dissolution of orthopyroxene remnants in transitional harzburgite and coarse-grained dunite.

\subsection{Synthesis and geotectonic implications}

Overall data show that the Vourinos mantle suite initially most likely evolved as an upwelling asthenospheric diapir under a mid-ocean spreading center that was afterward entrapped in the mantle wedge above a subduction zone. In particular, the studied peridotites resemble fore-arc peridotites containing accessory spinels with elevated Cr\# (up to 0.80, e.g., Arai 1994b; Ohara and Ishii 1998; Ahmed and Arai 2002; Murray 2007). Granular normal harzburgites containing blocky pyroxene and low $\mathrm{Cr} \#$ $(<0.60)$ anhedral chromian spinel are considered to be residual after a first-stage melting episode of a fertile peridotite under a mid-ocean spreading center. The generally low REE abundances in the studied peridotites are considered to have resulted from $\mathrm{H}_{2} \mathrm{O}$ assisted re-melting of a mantle wedge, which did not undergo any other significant enrichment by fluids except for $\mathrm{H}_{2} \mathrm{O}$ (Beccaluva et al. 2005). Water is known to be present in the mantle wedge above supra-subduction zones (e.g., Ahmed and Arai 2002; Andal et al. 2005; Uysal et al. 2005). Specifically, in a fore-arc geotectonic regime both water and depleted mantle are available, thus providing the ideal conditions for the formation of boninitic melts (e.g., Crawford et al. 1989; Pearce et al. 2000; Khalil and Azer 2008). Boninite release from the Vourinos mantle is supported by the U-shaped normalized REE patterns of the harzburgitic rocks and elevated $\mathrm{Cr} \#$ values of chromian spinel. In the fore-arc region peridotites are commonly affected by a combination of processes including partial melting and metasomatism, as it is the case for the investigated peridotites.

\section{Conclusions}

Normal harzburgite and coarse-grained dunite make up most of the Vourinos mantle suite, whereas transitional harzburgite and fine-grained dunite may locally also occur, the latter in contact with chromitites. Chromian spinel is anhedral in normal harzburgite, but turns to be more euhedral in all other peridotite types. Chromian spinel is characterized by increasing $\mathrm{Cr} \#$ values from normal harzburgite to coarse-grained dunite, which displays evidence for a multi-stage melting in the Vourinos mantle. Chromian spinel in fine-grained dunite bears compositional similarities with the same mineral from the adjacent chromitites, which further indicates their co-genetic origin from a reactive boninitic melt. After 
chromitite and fine-grained dunite formation the remnant melt could have invaded the adjacent peridotites to modify their chromian spinels or to crystallize new ones. The U-shaped REE patterns of the harzburgitic peridotites from the Voidolakkos district support their origin by interaction between an external metasomatic agent of boninitic affinity and depleted peridotites, most likely in a fore-arc setting.

Acknowledgements. This paper is based in part on the $\mathrm{Ph} . \mathrm{D}$. thesis of A. Kapsiotis at the University of Patras, Greece. Drs. A. Rassios and M. Ohnenstetter are gratefully acknowledged for their constructive criticism and helpful comments. Special thanks are also due to Dr. V. Janoušek and Prof. M. Štemprok for their editorial comments, linguistic help and technical assistance in the preparation of the manuscript. The author is thankful to Prof. K. Hatzipanagiotou for his encouragement and those colleagues from the Department of Geology at the University of Patras who did not tire in sharing ideas. V. Kotsopoulos of the Laboratory of Electron Microscopy and Microanalysis, University of Patras, is also acknowledged for his assistance with the microanalyses and SEM micrographs. Research was partly supported by the University of Patras, 'K. Karatheodoris' program and Pythagoras I project, which is co-funded by the European Social Fund and national resources (EPEAK programme). A. Kapsiotis was also financially supported by the State Scholarship Foundation of Greece (IKY) during his Ph.D. study.

\section{References}

Ahmed AH, Arai S (2002) Unexpectedly high-PGE chromitite from the deeper mantle section of the northern Oman Ophiolite and its tectonic implications. Contrib Mineral Petrol 143: 263-278

Ahmed AH, Arai S, Attia AK (2001) Petrological characteristics of podiform chromitites and associated peridotites of the Pan African Proterozoic ophiolite complexes of Egypt. Miner Depos 36: 72-84

Andal ES, Arai S, Yumul GP (2005) Complete mantle section of a slow-spreading ridge-derived ophiolite: an example from the Isabela Ophiolite in the Philippines. Island Arc 14: 272-294

ARAI S (1980) Dunite-harzburgite-chromitite complexes as refractory residue in the Sangun-Yamaguchi Zone, western Japan. J Petrol 21: 141-165

ARAI S (1992) Chemistry of chromian spinel in volcanic rocks as a potential guide to magma chemistry. Mineral Mag 56: 173-184

ARAI S (1994a) Characterization of spinel peridotites by olivine-spinel compositional relationships: review and interpretation. Chem Geol 113: 191-204
ARAI S (1994b) Compositional variation of olivine-chromian spinel in Mg-rich magmas as a guide to their residual spinel peridotites. J Volcanol Geotherm Res 59: 279-293

ARIF M, JAN MQ (2006) Petrotectonic significance of the chemistry of chromite in the ultramafic-mafic complexes of Pakistan. J Asian Earth Sci 27: 628-646

Bailey EH, Kemp AJ, Ragnarsdottija KV (1993) Determination of uranium and thorium in basalts and uranium in aqueous solution by inductively coupled plasma mass spectrometry. J Anal Atom Spectrom 8: 551-556

Beccaluva L, Ohnenstetter D, Ohnenstetter M, Paupy A (1984) Two magmatic series with island arc affinities within the Vourinos Ophiolites. Contrib Mineral Petrol 85: 253-271

Beccaluva L, Coltorti M, Saccani E, Siena F (2005) Magma generation and crustal accretion as evidenced by supra-subduction ophiolite of the Albanide-Hellenide Subpelagonian Zone. Island Arc 14: 551-563

BÉDARD JH, HÉBERT R (1998) Formation of chromitites by assimilation of crustal pyroxenites and gabbros into peridotite intrusions: North Arm Mountain Massif, Bay of Islands Ophiolite, Newfoundland, Canada. J Geophys Res 103: 5165-5184

Bizimis M, Salters VJM, Bonatti E (2000) Trace and REE content of clinopyroxenes from supra-subduction zone peridotites. Implications for melting and enrichment processes in island arcs. Chem Geol 165: 67-85

BRUNN JH (1956) Contribution à l' étude géologique du Pinde septentrional et d' une partie de la Macédoine occidentale. Ann Géol Pays Hell 7: 358

Crawford AJ, Faloon TJ, Green TH (1989) Classification, petrogenesis and tectonic setting of boninites. In: Crawford AJ (ed) Boninites and Related Rocks. Unwin Hyman, London, pp 1-49

Dai JG, Wang C-S, Hébert R, Santosh M, Li Y-L, Xu J-Y (2011) Petrology and geochemistry of peridotites in the Zongba Ophiolite, Yarlung Zangbo Suture Zone: implications for the Early Cretaceous intra-oceanic subduction zone within the Neo-Tethys. Chem Geol 288: 133-148

De Hoog JCM, Janák M, Vrabec M, Froitzheim N. (2008) Serpentinised peridotites from an ultrahigh-pressure terrane in the Pohorje Mts. (Eastern Alps, Slovenia): geochemical constraints on petrogenesis and tectonic setting. Lithos 109: 209-222

Delavari M, Amini S, Saccani E, Beccaluva L (2009) Geochemistry and petrogenesis of mantle peridotites from the Nehbandan Ophiolitic Complex, Eastern Iran. J Appl Sci 15: 2671-2687

Dick HJB, Bullen T (1984) Chromian spinel as a petrogenetic indicator in abyssal and Alpine-type peridotites and spatially associated lavas. Contrib Mineral Petrol 86: 54-76

Dijkstra AH, DruRy M, Mason PRD, Vissers RLM (2001) Structural petrology of plagioclase peridotites in the West 
Othris Mountains (Greece): melt impregnation in mantle lithosphere. J Petrol 42: 5-24

DijKstra AH, DruRy MR, Vissers RVM, Newman J (2002) On the role of melt-rock reaction in mantle shear zone formation in the Othris Peridotite Massif (Greece). J Struct Geol 24: 1431-1450

GHIKAS C (2007) Structure and tectonics of a subophiolitic mélange (Zavordas mélange) of the Vourinos Ophiolite (Greece) and kinematics of ophiolite emplacement. Unpublished MSci thesis, Miami University, Oxford, Ohio, pp 1-121

Ghikas C, Dilek Y, Rassios AE (2009) Structure and tectonics of subophiolitic mélanges in the western Hellenides (Greece): implications for ophiolite emplacement tectonics. Int Geol Rev 52: 423-453

Godard M, Jousselin D, Bodinier JL (2000) Relationships between geochemistry and structure beneath a paleospreading centre: a study of the mantle section in the Oman Ophiolite. Earth Planet Sci Lett 180: 133-148

Godard M, Lagabrielle Y, Alard O, Harvey J (2008) Geochemistry of the highly depleted peridotites drilled at ODP Sites 1272 and 1274 (Fifteen-Twenty Fracture Zone, Mid-Atlantic Ridge): implications for mantle dynamics beneath a slow spreading ridge. Earth Planet Sci Lett 267: 410-425

González-Jimenéz JM, Proenza JA, Gervilla F, MelgaRejo JC, Blanco-Moreno JA, Ruiz-Sánchez R, Griffin WL (2011) High-Cr and high-Al chromitites from the Sagua de Tánamo district, Mayarí-Cristal Ophiolitic Massif (eastern Cuba): constraints on their origin from mineralogy and geochemistry of chromian spinel and platinum-group elements. Lithos 125: 101-121

Grammatikopoulos TA, Kapsiotis A, Tsikouras B, Hatzipanagiotou K, Zaccarini F, Garuti G (2011) Spinel composition, PGE geochemistry and mineralogy of the chromitites from the Vourinos Ophiolite Complex, northwestern Greece. Canad Mineral 49: 1571-1598

Grieco G, Merlini A (2011) Chromite alteration processes within Vourinos Ophiolite. Int J Earth Sci 101: $1523-1533$

Harkins M, Green H, Moores E (1980) Multiple intrusive events documented from the Vourinos Ophiolite Complex, northern Greece. Amer J Sci 280: 284-290

Hellebrand E, Snow JE, Dick HJB, Hofmann AW (2001) Coupled major and trace elements as indicator of the extent of melting in mid-ocean-ridge peridotites. Nature 410: 677-681

Ishit T, Robinson PT, Maekawa H, Fiske R (1992) Petrological studies of peridotites from diapiric serpentinite seamounts in the Izu-Mariana fore-arc, Leg 125. In: Fryer P, Pearce JA, Stokking LB (eds) Proceedings of the Ocean Drilling Program, Scientific Results, College Station 125: 445-485

Ismail SA, Arai S, Ahmed AH, Shimizu Y (2009) Chromitite and peridotite from Rayat, northeastern Iraq, as fragments of Tethyan Ophiolite. Island Arc 18: 175-183

Juteau T, Berger E, Cannat M (1990) Serpentinized, residual mantle peridotites from the M.A.R. median valley, ODP hole $670 \mathrm{~A}\left(21^{\circ} 10^{\prime} \mathrm{N}, 45^{\circ} 02^{\prime} \mathrm{W}\right)$ : primary mineralogy and geothermometry. In: DetRick R, Honnorez J, Bryan WB, Juteau T (eds) Proceedings of the Ocean Drilling Program, Scientific Results, College Station 106 (109): 27-45

Kamenetsky VS, Crawford AJ, Mefrre S (2001) Factors controlling chemistry of magmatic spinel: an empirical study of associated olivine, Cr-spinel and melt inclusions from primitive rocks. J Petrol 42: 655-671

Kapsiotis A (2009) PGM and Chromite Mineralization Associated with the Petrogenesis of the Vourinos and Pindos Ophiolite Complexes, Northwestern Greece. Unpublished Ph.D. thesis, University of Patras, Patras, Greece, pp 1-891

Kapsiotis A, Tsikouras B, Karipi S, Grammatikopoulos T, Hatzipanagiotou K (2009) Petrogenesis and geotectonic significance of mantle peridotites from the Vourinos Ophiolite Complex (northern Greece). In: MontaninI A, Piccardo GB, Tribuzio R (eds) Alpine Ophiolites and Modern Analogues, Continental Rifting to Oceanic Lithosphere: Insights from the Alpine Ophiolites and Modern Oceans. Abstracts, Parma, 37-38

Kelemen PB, Dick HJB, Quick JE (1992) Formation of harzburgite by pervasive melt/rock reaction in the upper mantle. Nature 358: 635-641

Kelemen PB, Shimizu N, Salters VJM (1995) Extraction of mid-ocean ridge basalt from the upwelling mantle by focused melt in dunite channels. Nature 375: 747-753

Kelemen PB, Hirth G, Shimizu N, Sielgelman M, Dick HJB (1997) A review of melt migration processes in the adiabatically upwelling mantle beneath oceanic spreading ridges. Trans Roy Soc Lond 355: 283-318

Khalil AES, Azer MK (2008) Supra-subduction affinity in the Neoproterozoic serpentinites in the Eastern Desert, Egypt: evidence from mineral composition. J Afr Earth Sci 49: 136-152

Kuвo K (2002) Dunite formation processes in highly depleted peridotite: case study of the Iwanaidake peridotite, Hokkaido, Japan. J Petrol 43: 423-448

Leblanc M, Dupuy C, Cassard D, Moutte J, Nicolas A, PrinzHOFER A, RABINOVItCh M, Routhier P (1980) Essai sur la genèse des crops podiformes de chromitite dans les péridotites ophiolitiques: Étude des chromites de NouvelleCalédonie et comparaison avec celles de Méditerranée orientale. In: Panayiotou A (eds) Ophiolites. Geological Survey Department, Nicosia, Cyprus, pp 691-701

Le Roux V., Bodinier JL, Tommasi A, Alard O, Dautria JM, Vauchez A, Riches AJV (2007) The Lherz spinel lherzolite: refertilized rather than pristine mantle. Earth Planet Sci Lett 259: 599-612 
Lewis AJ, Palmer MR, Sturchio NC, Kemp AJ (1997) The rare earth element geochemistry of acid-sulphate-chloride geothermal systems from Yellowstone National Park, Wyoming, USA. Geochim Cosmochim Acta 61: 695-706

Li CN (1992) Trace-element petrology of igneous rocks. China University of Geosciences Press, Wuhan, pp 1-87

Liati A, Gebauer D, Fanning CM (2004) The age of ophiolitic rocks of the Hellenides (Vourinos, Pindos, Crete): first U-Pb ion microprobe (SHRIMP) zircon ages. Chem Geol 207:171-188

Matsumoto I, Arai S (2001) Morphological and chemical variations of chromian spinel in dunite-harzburgite complexes from the Sangun Zone (SW Japan): implications for mantle/melt reaction and chromitite formation processes. Mineral Petrol 73: 305-323

Matveev S, Ballhaus C (2002) Role of water in the origin of podiform chromitite deposits. Earth Planet Sci Lett 203: 235-243

McCulloch MT, Bennett VC (1994) Progressive growth of the Earth's continental crust and depleted mantle; geochemical constraints. Geochim Cosmochim Acta 58: 4717-4738

McDonough WF, Sun SS (1995) The composition of the Earth. Chem Geol 120: 223-253

Mercier JCC, Nicolas A (1975) Textures and fabrics of upper-mantle peridotites as illustrated by xenoliths from basalts. J Petrol 16: 454-487

Michibayashi K, Ohara Y, Stern RJ, Fryer P, Kimura JI, Tasaka M, Harigane Y, IshiI T (2009) Peridotites from a ductile shear zone within back-arc lithospheric mantle, southern Mariana Trench: results of a Shinkai 6500 dive. Geochem Geophys Geosyst 10: 1-17, doi: 10.1029/2008GC002197

Mikuš T, SPIŠIAK J (2007) Chemical composition and alteration of Cr-spinels from Meliata and Penninic serpentinized peridotites (Western Carpathians and Eastern Alps). Geol Quart 51: 257-270

Moores EM (1969) Petrology and Structure of the Vourinos Ophiolitic Complex of Northern Greece. Geological Society of America Special Papers 118: pp 3-66

MURRAY CG (2007) Devonian supra-subduction zone setting for the Princhester and Northumberland serpentinites: implications for the tectonic evolution of the northern New England Orogen. Aus J Earth Sci 54: 899-925

Myhill R (2011) Constraints on the evolution of the Mesohellenic Ophiolite from subophiolitic metamorphic rocks. In: WAKABAYASHI J, Dilek Y (eds) Mélanges: Processes of Formation and Societal Significance. Geological Society of America Special Papers 480: pp 75-94

Navon O, Stopler E (1987) Geochemical consequences of melt percolation: the upper mantle as a chromatographic column. J Geol 95: 285-307

Nicolas A (1989) Structures of Ophiolites and Dynamics of Oceanic Lithosphere. Kluwer Academic, Dordrecht, pp 1-367
Nicolas A, Poirier J (1976) Crystalline Plasticity and Solid State Flow in Metamorphic Rocks. Wiley, New York, pp 1-444

Ntaflos T, Bjerg EA, Labudia CH, Kurat G (2007) Depleted lithosphere from the mantle wedge beneath Tres Lagos, Southern Patagonia, Argentina. Lithos 94: 46-65

O'Driscoll B, Day JMD, Walker RJ, Daly S, McDonough W, PicCOLI PM (2012) Chemical heterogeneity in the upper mantle recorded by peridotites and chromitites from the Shetland Ophiolite Complex, Scotland. Earth Planet Sci Lett 333-334: 226-237

Ohara Y, Ishi T (1998) Peridotites from the southern Mariana forearc: heterogeneous fluid supply in the mantle wedge. Island Arc 7: 541-558

Okamura H, Arai S, Kim YU (2006) Petrology of fore-arc peridotite from the Hahajima Seamount, the Izu-Bonin arc, with special reference to chemical characteristics of chromian spinel. Mineral Mag 70: 15-26

OzaWa K (1989) Stress-induced Al-Cr zoning of spinel in deformed peridotites. Nature 338: 141-144

Parkinson IJ, Pearce JA (1998) Peridotites from the IzuBonin-Mariana fore-arc (ODP Leg 125): evidence for mantle melting and melt-mantle interaction in a suprasubduction zone setting. J Petrol 39: 1577-1618

Parkinson IJ, Pearce Ja, Thirlwall MF, Johnson KTM, INGRAM G (1992) Trace element geochemistry of peridotites from the Izu-Bonin-Mariana fore-arc, Leg 125. In: Fryer P, Pearce JA, Stokking LB (eds) Proceedings of the Ocean Drilling Program, Scientific Results, College Station 125: 487-506

Pearce JA, Barker PF, Edwards SJ, Parkinson IJ, Leat PT (2000) Geochemistry and tectonic significance of peridotites from the South Sandwich arc-basin system, South Atlantic. Contrib Mineral Petrol 139: 36-53

Rassios A, Dilek Y (2009) Rotational deformation in the Jurassic Mesohellenic Ophiolites, Greece, and its tectonic significance. Lithos 108: 207-223

Rassios A, Moores EM (2006) Heterogeneous mantle complex, crustal processes, and obduction kinematics in a unified Pindos-Vourinos Ophiolitic slab (northern Greece). In: Robertson AHF, Mountrakis D (eds) Tectonic Development of the Eastern Mediterranean Region. Geological Society of London Special Publications 260: pp 237-266

Rassios A, Sмith AG (2000) Constraints on the formation and emplacement age of western Greek ophiolites (Vourinos, Pindos and Othris) inferred from deformation structures in peridotites. In: Dilek Y, Moores EM, Elthon D, Nicolas A (eds) Ophiolites and Ocean Crust: New Insights from Field Studies and the Ocean Drilling Program. Geological Society of America Special Papers 349: pp 473-483

Rassios A, Grivas E, Konstantopoulou G, Vacondios I (1994) The geometry of structures forming around the ductile-brittle transition in the Vourinos-Pindos-Othris oceanic slab. Geol Soc Greece Bull 2: 109-121 
Roberts S, Rassios A, Wright L, Vacondios I, Vrachatis G, Grivas E, Nesbitt RW, Neary CR, Moat T, KonstanTOPOLOU G (1988) Structural controls on the location and form of the Vourinos chromite deposits. In: BoIssonAs J, Omenetto P (eds) Mineral Deposits Within the European Community. Springer-Verlag, Berlin, pp 249-266

Ross JV, Zimmerman J (1996) Comparison of evolution and tectonic significance of the Pindos and Vourinos ophiolite suites, northern Greece. Tectonophysics 256: 1-15

Saccani E, Photiades A, Beccaluva L (2008) Petrogenesis and tectonic significance of Jurassic IAT magma types in the Hellenide Ophiolites as deduced from the Rhodiani ophiolites (Pelagonian Zone, Greece). Lithos 104: 71-84

Seyler M, Lorand JP, Dick HJB, Drouin M (2007) Pervasive melt percolation reactions in ultra-depleted refractory harzburgites at the Mid-Atlantic Ridge, $15^{\circ} 20^{\prime} \mathrm{N}$ : ODP Hole 1274A. Contrib Mineral Petrol 153: 303-319

Spray JG, Roddick JC (1980) Petrology and ${ }^{40} \mathrm{Ar} /{ }^{39} \mathrm{Ar}$ geochronology of some Hellenic sub-ophiolite metamorphic rocks. Contrib Mineral Petrol 72: 43-55

Suhr G, Seck HA, Shimizu N, Gunther D (1998) Infiltration of refractory melts into the lowermost oceanic crust: evidence from dunite- and gabbro-hosted clinopyroxenes in the Bay of Islands Ophiolite. Contrib Mineral Petrol 131: 136-154

TAKaZawa E, OKayasu T, SATOH K (2003) Geochemistry and origin of the basal lherzolites from the northern Oman Ophiolite (northern Fizh Block). Geochem Geophys Geosyst 4: doi:10.1029/2001GC000232

Tamura A, Arai S, Ishimaru S, Andal ES (2008) Petrology and geochemistry of peridotites from IODP site U1309 at Atlantis Massif, MAR $30^{\circ} \mathrm{N}$ : micro- and macro-scale melt penetrations into peridotites. Contrib Mineral Petrol 155: 491-509
Uysal I, Sadiklar MB, Tarkian M, Karsli O, Aydin F (2005) Mineralogy and composition of the chromitites and their platinum-group minerals from Ortaca (Muğla - SW Turkey): evidence for ophiolitic chromitite genesis. Mineral Petrol 83: 219-242

Uysal I, Kaliwoda M, Karsli O, Tarkian M, Sadiklar MB, Ottley CJ (2007) Compositional variations as a result of partial melting and melt-peridotite interaction in an upper mantle section from the Ortaca area, southwestern Turkey. Canad Mineral 45: 1471-1493

Uysal I, Ersoy EY, Karsli O, Dilek Y, Sadiklar MB, Ottley CJ, Tiepolo M, Meisel T (2012) Coexistence of abyssal and ultra-depleted SSZ type mantle peridotites in a Neo-Tethyan ophiolite in SW Turkey: constraints from mineral composition, whole-rock geochemistry (major-trace-REE-PGE), and Re-Os isotope systematics. Lithos132-133: 50-69

Vils F, Pelletier L, Kalt A, Müntener O (2005) The Pindos and Vourinos ophiolites (northern Greece): mineral compositions and geothermometry. In: Geophysical Research Abstracts, EGU05-A-01986

Wiechert U, Ivanov DA, Wedepohl KH (1997) Spinel peridotite xenoliths from the Atsagin-Dush volcano, Dariganga lava plateau, Mongolia: a record of partial melting and cryptic metasomatism in the upper mantle. Contrib Mineral Petrol 126: 345-364

Xu YG, Menzies M, Thirlwall F, Huang XL, Liu Y, Chen XM (2003) "Reactive" harzburgites from Huinan, NE China: products of the lithosphere-asthenosphere interaction during lithospheric thinning? Geochim Cosmochim Acta 3: 487-505

Zhou MF, Robinson PT, Malpas J, Edwards SJ, Qi L (2005) REE and PGE geochemical constraints on the formation of dunites in the Luobusa Ophiolite, southern Tibet. J Petrol 46: 615-639 